\title{
THE RISE OF IT FOR ENTREPRENEURS AND THE INCREASING ENTREPRENEURIAL FOCUS FOR IT PROFESSIONALS
}

\author{
Bethany Davidson, Western Carolina University, bdavidson@email.wcu.edu \\ Barbara Jo White, Western Carolina University, whiteb@email.wcu.edu \\ Michael Taylor, Western Carolina University, mdtaylor4@catamount.wcu.edu
}

\begin{abstract}
Entrepreneurs are one of the major driving forces of the economy and will likely lead it out of the current recession. Entrepreneurship programs and courses at institutions of higher education are flourishing with increasing enrollments. This trend towards an increasing entrepreneurial focus has not bypassed the Information Technology (IT) department; even Chief Information Officers (CIOs) are becoming increasingly entrepreneurial. At the same time that IT is becoming more entrepreneurial, entrepreneurs have also shown an increasing focus on the use of IT. This paper illustrates the intersection of business and technology priorities for IT professionals and entrepreneurs and the relationship of those priorities to typical topics covered in the core Computer Information Systems (CIS) course required for most business and entrepreneurship students.
\end{abstract}

Keywords: Entrepreneurship, IT, CIO, Curriculum

\section{INTRODUCTION}

Entrepreneurs are one of the driving forces of the U.S. economy. According to the U.S. Small Business Administration, small businesses represent $99.7 \%$ of all employer firms, employ about half of all private sector employees, and hire $43 \%$ of high tech workers [27]. Entrepreneurial activity is widespread with 1 in 12 adults participating in the launch of a new firm, and 1 in 150 adults participating as founding owners of a new entrepreneurial firm, each year [19]. Often these entrepreneurs use technology as a major part of their launch strategy. In fact, entrepreneurs across the globe are increasingly leveraging technology such as the Internet to develop their new ventures [18].

At the same time that entrepreneurs are increasingly using and seeking out IT related knowledge and skills, IT is becoming more entrepreneurial with CIOs increasingly focused on priorities once reserved for entrepreneurs. This increased focus on entrepreneurship and the need for entrepreneurial skills has not been lost on colleges and universities; over 1600 colleges and universities currently offer at least one entrepreneurship course [19]. In addition, IT services vendors are dealing with a growing demand from small and medium enterprises (SMEs) for assistance with their technical needs.

Given that CIOs are concerned with entrepreneurial concepts such as innovation and that entrepreneurs need ITrelated skills, it would be prudent to better understand the IT skills offered by CIS courses in colleges of business. This paper illustrates the intersection of business and technology priorities for IT professionals and entrepreneurs and the relationship of those priorities to typical topics covered in the core Computer Information Systems (CIS) course required for most business students including entrepreneurship students.

\section{INCREASING ENTREPRENEURIAL FOCUS OF CHIEF INFORMATION OFFICERS}

How can organizations deliver on the high expectations for growth in an environment where investment capital is significantly constrained and risks are held high? The answer is that IT and associated business unit organizations must think like entrepreneurs: They must establish an ambition for themselves that is beyond their existing resources. [21, pg.1]

$$
\text { Jorge Lopez, Gartner Analyst }
$$




\section{Issues in Information Systems}

Volume 13, Issue 2, pp. 104-111, 2012

Technological change and increases in productivity are often due to innovations created by the activities of entrepreneurial firms and their employees [19]. Innovation, according to Gartner which regularly surveys CIOs regarding their top business priorities, was ranked \#4 on the 2011 list of priorities, up from \#10 in 2007 (see Table 1 on the following page). No other priority on the CIO's list for 2011 showed as dramatic a rise on the priority list. Activities such as creating new products and services and reducing product development cycles, identified in Gartner's survey as related to innovation, are activities that are typically the purview of entrepreneurs. With CIOs also concerned about these innovation-related priorities, it appears that CIO priorities are becoming increasingly entrepreneurial in nature. In addition, it may be argued that business priorities such as attracting new customers, reducing costs, entering new markets and increasing enterprise workforce effectiveness, priorities that also appear high on the list of CIO business priorities, are also innovation-related.

Table 1. Top 10 Business Priorities for 2007-2011 from Gartner Surveys of CIOs

\begin{tabular}{|c|c|c|c|c|c|}
\hline $\begin{array}{l}\text { Business Priorities } \\
\text { (multiple terms reflect changes in Gartner survey terminology over the } \\
\text { 2007-2011 period) }\end{array}$ & $\begin{array}{l}2011 \\
{[13]}\end{array}$ & $\begin{array}{l}2010 \\
{[12]}\end{array}$ & $\begin{array}{r}2009 \\
{[11]}\end{array}$ & $\begin{array}{l}2008 \\
{[10]}\end{array}$ & $\begin{array}{c}2007 \\
{[9]}\end{array}$ \\
\hline Increasing enterprise growth & 1 & & & & \\
\hline $\begin{array}{l}\text { Attracting and retaining new customers; Attract, retain and grow customer } \\
\text { relationships }\end{array}$ & 2 & 5 & 4 & 2 & 3 \\
\hline Reducing enterprise costs; Controlling enterprise wide operating costs & 3 & 2 & 2 & 5 & 2 \\
\hline $\begin{array}{l}\text { Creating new products or services (innovation); Faster innovation (shorter } \\
\text { product/service life cycles) }\end{array}$ & 4 & 7 & 6 & 3 & 10 \\
\hline Improving business processes; Business process improvement & 5 & 1 & 1 & 1 & 1 \\
\hline Implementing and updating business applications & 6 & & & & \\
\hline Improving technical infrastructure & 7 & & & & \\
\hline Improving enterprise efficiency & 8 & & & & \\
\hline Improve operations & 9 & & & & \\
\hline Improve business continuity, risk and security & 10 & & & & \\
\hline $\begin{array}{l}\text { Increasing the use of information / analytics; Expanding the use of } \\
\text { information/intelligence in products and services }\end{array}$ & & 3 & 5 & 8 & 7 \\
\hline Improving enterprise workforce effectiveness & & 4 & 3 & 6 & 4 \\
\hline Managing change initiative & & 6 & 8 & & \\
\hline Targeting customers and markets more effectively & & 8 & 7 & 9 & \\
\hline Consolidating business operations & & 9 & & & \\
\hline Expanding current customer relationships & & 10 & 9 & 7 & \\
\hline $\begin{array}{l}\text { Expanding into new markets or geographies; Entering new markets, new } \\
\text { products or new services }\end{array}$ & & & 10 & 4 & 9 \\
\hline Acquiring new companies and capabilities (mergers and acquisitions) & & & & 10 & \\
\hline Revenue growth; Need for revenue growth & & & & & 5 \\
\hline $\begin{array}{l}\text { Improving competitiveness; Improving enterprise competitiveness (bottom } \\
\text { line profitability) }\end{array}$ & & & & & 6 \\
\hline Deploying new business capabilities to meet strategic goals & & & & & 8 \\
\hline
\end{tabular}

Not only have CIO business priorities changed over time, but technology priorities for CIOs have also changed. 


\section{Issues in Information Systems}

Volume 13, Issue 2, pp. 104-111, 2012

In Table 2 on the following page, we can see that technology priorities that once remained steadily at the top of the priority list, such as business intelligence and enterprise systems, were supplanted in 2010 by newly-appearing priorities such as cloud computing and mobile technologies. These technologies currently represent two of the top three macro trends [4] and technological priorities [14] affecting the IT strategies of SMEs. The third macro trend, according to Gartner [4], is virtualization. Technology spending is likely to be focused in these macro trend areas which comprised the top three technology priorities for CIOs in 2011.

Table 2. Top 10 Technology Priorities 2005-2011 Gartner Surveys of CIOs

\begin{tabular}{|c|c|c|c|c|c|c|c|}
\hline $\begin{array}{l}\text { Technology Priorities } \\
\text { (multiple terms reflect changes in Gartner } \\
\text { survey terminology over the 2005-2011 period) }\end{array}$ & $\begin{array}{l}2011 \\
{[13]}\end{array}$ & $\begin{array}{c}2010 \\
{[12]}\end{array}$ & $\begin{array}{l}2009 \\
{[11]}\end{array}$ & $\begin{array}{l}2008 \\
{[10]}\end{array}$ & $\begin{array}{c}2007 \\
{[9]}\end{array}$ & $\begin{array}{c}2006 \\
{[8]}\end{array}$ & $\begin{array}{c}2005 \\
{[7]}\end{array}$ \\
\hline Cloud computing & 1 & 2 & & & & & \\
\hline $\begin{array}{l}\text { Virtualization; Servers and storage technologies; } \\
\text { Servers and storage technologies (virtualization); } \\
\text { Virtualization; Server virtualization }\end{array}$ & 2 & 1 & 3 & 3 & 5 & 9 & 10 \\
\hline Mobile technologies & 3 & 6 & & & & & \\
\hline IT management & 4 & 10 & & & & & \\
\hline $\begin{array}{l}\text { Business intelligence; Business Intelligence } \\
\text { applications }\end{array}$ & 5 & 5 & 1 & 1 & 1 & 1 & 2 \\
\hline $\begin{array}{l}\text { Networking, voice and data; Networking, voice and } \\
\text { data communications; Voice and data integration } \\
\text { over IP }\end{array}$ & 6 & 4 & 6 & 7 & 4 & 8 & 7 \\
\hline $\begin{array}{l}\text { Enterprise applications (ERP, CRM and others); } \\
\text { Enterprise resource planning upgrades }\end{array}$ & 7 & & 2 & 2 & 2 & & 5 \\
\hline Collaboration technologies & 8 & & 5 & 8 & 10 & 4 & \\
\hline $\begin{array}{l}\text { Infrastructure; Technical infrastructure } \\
\text { management; Technical infrastructure }\end{array}$ & 9 & & 7 & 5 & 8 & & \\
\hline Web 2.0 & 10 & 3 & & & & & \\
\hline $\begin{array}{l}\text { Data/document management and storage; Document } \\
\text { management }\end{array}$ & & 7 & 10 & 9 & 9 & & \\
\hline $\begin{array}{l}\text { Service-oriented applications and architecture; } \\
\text { Service-oriented architecture (SOA) and service- } \\
\text { oriented business applications (SOBA); Service- } \\
\text { oriented architectures }\end{array}$ & & 8 & 9 & 10 & 7 & 6 & \\
\hline Security technologies; Security enhancement tools & & 9 & 8 & 6 & 6 & 2 & 1 \\
\hline $\begin{array}{l}\text { Legacy modernization; Legacy application } \\
\text { modernization }\end{array}$ & & & 4 & 4 & 3 & 10 & \\
\hline Mobile workforce enablement & & & & & & 3 & 3 \\
\hline Customer sales and service & & & & & & 5 & \\
\hline $\begin{array}{l}\text { Workflow management; Workflow management } \\
\text { deployment and integration }\end{array}$ & & & & & & 7 & 4 \\
\hline Customer relationship management (CRM) & & & & & & & 8 \\
\hline Storage management & & & & & & & 6 \\
\hline Business process integration tools & & & & & & & 9 \\
\hline
\end{tabular}




\title{
Issues in Information Systems
}

Volume 13, Issue 2, pp. 104-111, 2012

IT spending by entrepreneurs on priorities like those listed in Table 2 above, is predicted to grow at a healthy 5.3\% through 2012. In fact, small and medium enterprises (SMEs) are expected to spend over \$900 billion on IT in 2012 and over $\$ 1$ trillion in 2014 [4]. IT service providers must understand the unique and changing priorities of SMEs if these vendors are going to capture a share of that spending [4].

Typically, entrepreneurs are looking for IT solutions that can be characterized as solutions that need minimal customization, are easy to install, manage and integrate with current systems and perhaps most importantly, are IT solutions that come with a higher-than-normal level of support [4]. Technologies that are top priorities for small and medium businesses include virtualization, mobile computing, customer relationship management (CRM), business intelligence, storage, security, and cloud computing [4]. It is no surprise that the entrepreneurs' technology priorities align well with the technology priorities of CIOs who are increasingly becoming more entrepreneurial.

\section{INCREASING TECHNOLOGICAL FOCUS OF ENTREPRENEURS}

\begin{abstract}
"What is the nature of the relationship between IT and entrepreneurism (either small start-ups or intrapreneurial ventures within large multinationals)? Our steadfast belief is that IT is the magic ingredient that inspires and most often enables contemporary entrepreneurial endeavors. Our argument is that it is more like a long-standing marriage than a transient love affair." [6, pg. iii]
\end{abstract}

Manlio Del Giudice and Detmar Straub

A characteristic of successful entrepreneurs and firms is their ability to capitalize on individual and firm-level skills and knowledge [26, 18]. Skills such as finance, marketing, operations, human resources, and accounting historically appear on lists of skills entrepreneurs need (see Table 3 below); however, the list of skills entrepreneurs need for success has become increasingly technology-oriented over time. Information technology is strategically important for entrepreneurs since constantly combining tools and technologies can add value for both the entrepreneurs and their customers [26]. Even innovations that are not directly technical in nature rely on a wide-range of technologies to design, build, and market them [6]. In fact, firms with entrepreneurs who cultivate their technology skills are better able to leverage and connect new and existing technologies and are typically more successful [26].

Table 3. Changes in Entrepreneurial Skills (Non-Technology-Focused and Technology-Focused) Over Time

\section{ENTREPRENEURIAL SKILLS}

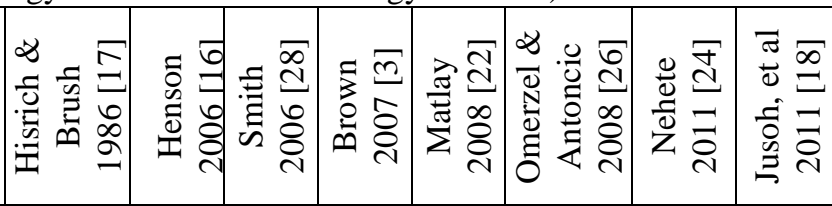

\begin{tabular}{|c|c|c|c|c|c|c|c|c|}
\hline \multicolumn{9}{|l|}{ NON-TECHOLOGY-FOCUSED SKILLS } \\
\hline Finance & $\bullet$ & $\bullet$ & $\bullet$ & - & $\bullet$ & $\bullet$ & - & $\bullet$ \\
\hline Marketing & $\bullet$ & - & $\bullet$ & - & $\bullet$ & $\bullet$ & $\bullet$ & - \\
\hline Human resources/Organizational behavior & $\bullet$ & $\bullet$ & $\bullet$ & $\bullet$ & $\bullet$ & $\bullet$ & $\bullet$ & $\bullet$ \\
\hline Strategic Management & - & - & - & - & - & - & & - \\
\hline Operations/Productions & - & - & - & - & & - & - & - \\
\hline Accounting & & $\bullet$ & $\bullet$ & $\bullet$ & & $\bullet$ & $\bullet$ & $\bullet$ \\
\hline Legal and Ethics & & $\bullet$ & $\bullet$ & & & $\bullet$ & $\bullet$ & $\bullet$ \\
\hline $\begin{array}{l}\text { Emotional Coping; Managing Themselves; Time } \\
\text { Management; Life Skills }\end{array}$ & & & - & & • & $\bullet$ & • & $\bullet$ \\
\hline $\begin{array}{l}\text { Idea Development/Innovation/Research and } \\
\text { Development }\end{array}$ & • & & & & $\bullet$ & & - & • \\
\hline Business Concept & & & $\bullet$ & & & $\bullet$ & & $\bullet$ \\
\hline $\begin{array}{l}\text { Decision Making/Problem Solving/Critical Thinking } \\
\text { and Analytical Skills }\end{array}$ & & - & - & & & $\bullet$ & & \\
\hline Personal Maturity: Creativity, Accountability; Self- & & & $\bullet$ & & & & & \\
\hline
\end{tabular}




\section{Issues in Information Systems}

Volume 13, Issue 2, pp. 104-111, 2012

\begin{tabular}{|l|l|l|l|l|l|l|l|l|}
\hline Awareness & & & & & & \\
\hline Production/Office Layout/Equipment Planning & & & $\bullet$ & & & & \\
\hline TECHNOLOGY-FOCUSED SKILLS & & & $\bullet$ & & & $\bullet$ & $\bullet$ & $\bullet$ \\
\hline $\begin{array}{l}\text { Supplies/Raw Materials Procurement/Supply Chain } \\
\text { Management/Supplier Management/Logistics }\end{array}$ & & & & $\bullet$ & & & $\bullet$ & \\
\hline $\begin{array}{l}\text { Information Management and Technical Computer } \\
\text { Literacy }\end{array}$ & & & & & & $\bullet$ & & $\bullet$ \\
\hline E-Commerce and Internet & & & & & & & & $\bullet$ \\
\hline Excel, Word and Other Software Applications & & & & & \\
\hline
\end{tabular}

As we can see in Table 3 on the previous page, the list of skills needed for entrepreneurial success has evolved over time to include an increasingly wider range of technical knowledge and skills including: logistics, information management, e-commerce and the Internet, and software applications. Entrepreneurs and SMEs without direct access to technology skills and knowledge may turn to IT services vendors to provide them with the IT knowledge and capabilities they lack. In addition, entrepreneurs and potential future entrepreneurs are also looking to entrepreneurship degree programs to provide them with the business and technical skills they need.

\section{ENTREPRENEURSHIP EDUCATION AND ACQUISITION OF IT SKILLS}

The demand for entrepreneurial knowledge and skills is reflected in the rapid growth of colleges and universities offering courses or degree programs in entrepreneurship. U.S. colleges and universities offering entrepreneurship courses have rapidly expanded from a handful of colleges and universities offering courses in the 1970 s, to 300 in the 1980 s, over 1,000 by 2000 , to over 1,600 universities offering entrepreneurship courses today [19]. Growth in entrepreneurship course and program offerings is also occurring in community colleges with at least $66 \%$ of U.S. community colleges offering courses in entrepreneurship and $14 \%$ of community colleges offering a 2-year entrepreneurship degree [23].

Entrepreneurship students typically acquire their IT knowledge and skills from various CIS or MIS courses offered in colleges of business. Most often, there is a core CIS or MIS class that all business majors, including entrepreneurship majors, must take. The Association to Advance Collegiate Schools of Business (AACSB), the international accrediting body for business schools, emphasizes topic relevance and currency in business school curriculum specifically citing "...the need for graduates to be competent in the uses of technology and information systems in modern organizational operations" [1, pg.70].

There are also national guidelines, such as IS 2010, the model curriculum guideline for undergraduate degree programs in information systems, that suggest topics relevant for the CIS core and related courses [29]. IS 2010 is a major update from previous versions in that it focuses less on technical issues and more on managerial issues relating to information systems management [29]. It seems ironic for IS 2010 to be focusing on management at a time when entrepreneurs are increasingly focused on acquiring technical skills to meet business priorities. However, this may actually be illustrating the need for entrepreneurs to first understand basic IT skills before they are able to effectively manage IT utilizing vendors or employees.

\section{Topics Covered in Core Information Systems Courses for Business Majors}

The IS 2010 model curriculum guidelines suggest a core business course that covers the following topics [29]:

Topic 1: Information systems components

Topic 2: Information systems in organizations

Topic 3: Globalization

Topic 4: Valuing information systems

Topic 5: Information systems infrastructure

Topic 6: The Internet and WWW

Topic 7: Security of information systems 


\section{Issues in Information Systems}

Volume 13, Issue 2, pp. 104-111, 2012

Topic 8: Business intelligence

Topic 9: Enterprise-wide information systems

Topic 10: Development and acquisition

Topic 11: Information systems ethics and crime

It is no coincidence that many of the IS 2010 model curriculum guidelines for the core CIS course also appear in the core CIS course textbooks. The IS 2010 revision is the third revision to the suggested core CIS course for business majors since 1997, while textbooks designed for the same core CIS course are revised much more frequently. Even 2012 textbooks appear to be lagging behind the technology and business priorities reported in the Gartner surveys. For example, an analysis of chapter numbers and headings from current textbooks typically used in core CIS courses (see Table 4 on the following page) indicates that technology macro trends such as cloud computing, mobile technologies, and virtualization are not listed as major topics in the textbooks.

Table 4: Topics Covered in Common Core CIS/MIS Course Textbooks

\begin{tabular}{|l|c|c|c|c|c|}
\hline $\begin{array}{l}\text { Textbook Topic With Associated Chapter or Appendix } \\
\text { Number Under Which It Appears }\end{array}$ & $\begin{array}{c}\text { Laudon } \\
\text { Laudon } \\
\text { Cummings } \\
2012[20]\end{array}$ & $\begin{array}{c}\text { O'Brien } \\
\& \\
\text { Marakas } \\
\text { Cummings } \\
2012[25]\end{array}$ & $\begin{array}{c}\text { Baltzan } \\
\text { Cummings } \\
2012[2]\end{array}$ & $\begin{array}{c}\text { Vacich } \\
\text { Schneider } \\
\text { Cummings } \\
2012[30]\end{array}$ & $\begin{array}{c}\text { Haag } \\
\& \\
\text { Cummings } \\
2013[15]\end{array}$ \\
\hline Info Systems in (Global) Business & 1 & 1 & 1 & 1 & 1 \\
\hline Business Processes and IS & 2 & 7 & 2 & 3 & 1 \\
\hline Competitive Advantage with IT; Value Chain & 3 & 2 & 1 & 2 & 2 \\
\hline Ethical and Social Issues & 4 & 13 & 4 & 1 & 8 \\
\hline Hardware & 5 & 3 & 5 & 1, A1 & 1, A1 \\
\hline Software & 5 & 4 & 5 & 1, A2 & 1, A1 \\
\hline BI: Databases and Data Mining & 6 & 5 & 6 & 3 & 3 \\
\hline Networks \& Telecommunications & 7 & 6 & 7, A2 & 4, A3 & A5 \\
\hline IT Security & 8 & 13 & 4 & 10 & 8 \\
\hline Supply Chain Mgmt & 9 & 8 & 8 & 8 & 2 \\
\hline Customer Relationship Mgmt. & 9 & 8 & 8 & 8 & 2 \\
\hline Enterprise Resource Planning & 9 & 8 & 8 & 7 & 7 \\
\hline E-Commerce and E-Business & 10 & 9 & 3 & 4 & 5 \\
\hline AI, Gen. Alg., KM, Expert Sys., Neural Nets & 11 & 10 & 2 & 8 & 4 \\
\hline DSS, ESS, GDSS, EIS & 12 & 10 & 2 & 8 & 4 \\
\hline Developing IT Systems & 13 & 12 & 9 & 9, A3 & 6 \\
\hline Proj. Mgmt; Bus. Value of IT; Implementation & 14 & 12 & 9 & 7 & 6 \\
\hline Managing Global IT; Sourcing & 15 & 14 & 9 & 2 & 6 \\
\hline
\end{tabular}

\section{CONCLUSIONS}

The role of IT in entrepreneurship, according to IT researchers Straub and Del Giudice [6], cannot be underestimated. "During the past 15 years, IT has played a central role in the entrepreneurial development of virtually every country in the world, as well as contributing crucially to the performance of advanced economies." 6 , p. iv]. Education is very important for entrepreneurs; their knowledge, particularly their knowledge of technology skills, directly affects the growth and profitability of the firm [26]. Business and technology priorities of entrepreneurs and CIOs are becoming more closely aligned over time. Given the alignment between entrepreneur and CIO business and technical priorities, it is incumbent on professors of information systems to stay abreast of technology developments in both fields as entrepreneurs increasingly seek out the technology knowledge and skills they need either from educational institutions such as colleges and universities or from employees or technology vendors who understand the needs of SMEs. Colleges and universities and IT services vendors should be certain 


\section{Issues in Information Systems}

Volume 13, Issue 2, pp. 104-111, 2012

that they are meeting the current needs of their entrepreneurial customers as well as keeping up with changing technology needs.

\section{REFERENCES}

1. AACSB International (2011, January). Eligibility procedures and accreditation standards for business accreditation. St. Louis: Author.

2. Baltzan, P. (2012). Business driven information systems, $3^{\text {rd }}$ ed. New York, NY: McGraw-Hill Irwin

3. Brown, S. (2007). Seven skills for the aspiring entrepreneur. Business \& Economic Review, 16-18.

4. Browning, J. A. (2011). Agenda for small and midsize business go-to-market strategy, 2012. Gartner.com. Available: www.gartner.com/id=1918914.

5. Browning, J. A. (2012). Key issues for IT providers targeting the SMB market in 2011. Gartner.com. Available: www.gartner.com/id=1309016.

6. Del Giudice, M. and Straub, D. (2011). IT and entrepreneurism: An on-again, off-again love affair or a marriage? MIS Quarterly, 35(4), iii-vii.

7. Gartner (2005). Gartner Survey of 1300 CIOs Shows IT Budgets to Increase by 2.5 Percent in 2005. Gartner Press Release. Available: www.gartner.com/press_releases/asset_117739_11.html

8. Gartner. (2006). Gartner Survey of 1400 CIOs Shows Transformation of IT Organisation is Accelerating. Gartner Press Release. Available: www.gartner.com/it/page.jsp?id=492238.

9. Gartner. (2007). Gartner EXP Survey of then 1400 CIOs Shows CIOs Must Create Leverage to Remain Relevant to the Business. Gartner Press Release. Available: www.gartner.com/it/page.jsp?id=501189.

10. Gartner. (2008). Gartner EXP Worldwide Survey of 1,500 CIOs Shows 85 Percent of CIOs Expect "Significant Change" Over Next Three Years. Gartner Press Release. Available: www.gartner.com/it/page.jsp?id=587309.

11. Gartner. (2009). Gartner EXP Worldwide Survey of More than 1,500 CIOs Shows IT Spending to Be Flat in 2009. Gartner Press Release. Available: www.gartner.com/it/page.jsp?id=855612.

12. Gartner. (2010). Gartner EXP Worldwide Survey of Nearly 1,600 CIOs Shows IT Budgets in 2010 to be at 2005 Levels. Gartner Press Release. Available: www.gartner.com/it/page.jsp?id=1283413.

13. Gartner. (2011). Gartner Executive Programs Worldwide Survey of More Than 2,000 CIOs Identifies Cloud Computing as Top Technology Priority for CIOs in 2011. Gartner Press Release. Available: www.gartner.com/it/page.jsp?id=1526414.

14. Gartner. (2012). Gartner Executive Programs Worldwide Survey of More Than 2,300 CIOs Shows Flat IT Budgets in 2012, but IT Organizations Must Deliver on Multiple Priorities. Gartner Press Release. Available: www.gartner.com/it/page.jsp?id=1897514.

15. Haag, S., Cummings, M. (2013). Management Information Systems for the Information Age $9^{\text {th }}$ ed. New York, NY: McGraw-Hill Irwin.

16. Henson, S., Williamson, S., Jacques, P. (2006). Business training and education needs of audiology managers, Audiology Today, 19(2), 49-54.

17. Hisrich, R. D., \& Brush, C. (1986). Characteristics of the minority entrepreneur. Journal of Small Business Management, 24, 1-8.

18. Jusoh, R., Ziyae, B., Asimiran, S. and Kadir, S. A. (2011). Entrepreneur training needs analysis: implications on the entrepreneurial skills needed for successful entrepreneurs. The International Business \& Economics Research Journal, 10(1), 143-148.

19. Kuratko, D. F. (2005). The emergence of entrepreneurship education: Development, trends, and challenges. Entrepreneurship: Theory and Practice, 29(5), 577-597.

20. Laudon, K. \& Laudon, J. (2012). Management Information Systems: Managing the Digital Firm, $12^{\text {th }}$ ed. New Jersey: Pearson Education.

21. Lopez, J. (2010). How entrepreneurial does IT have to be? Gartner.com. Available www.gartner.com/id=1445330.

22. Matlay, H. (2008). The impact of entrepreneurship education on entrepreneurial outcomes. Journal of Small Business and Enterprise Development, 15(2), 382-396.

23. National Association for Community College Entrepreneurship (NACCE). (n.d.) Fact sheet. Available: www.nacce.com/resource/resmgr/docs/nacce_fact_sheet_updated2.pdf 


\section{Issues in Information Systems}

Volume 13, Issue 2, pp. 104-111, 2012

24. Nehete, R. S., Narkhede, B. E., Mahajan, S. K. (2011). IS 2010: Investigation of entrepreneurial skills for better performance of SMEs. International Journal of Engineering Science and Technology, 3(7), 5515-5525.

25. O’Brien, J. \& Marakas, G. (2012). Management Information Systems, $10^{\text {th }}$ ed. Boston: McGraw-Hill/Irwin.

26. Omerzel, D. G. and Antoncic, B. (2008). Critical entrepreneur knowledge dimensions for the SME performance, Industrial Management \& Data Systems, 108 (9), 1182-1199.

27. Small Business Administration. (2011). Frequently Asked Questions. Available: http://web.sba.gov/faqs/faqIndexAll.cfm?areaid=24.

28. Smith, W. L., Schallenkamp, K., \& Eichholz, D. E. (2007). Entrepreneurial skills assessment: an exploratory study, International Journal of Management and Enterprise Development, 4(2), 179-201.

29. Topi, H., Valacich, J. S., Wright, R. T., Kaiser, K., Nunamaker, Jr., J. F., Sipior, J. C., \& de Vreede, G. J. (2009). IS 2010: Curriculum guidelines for undergraduate degree programs in information systems. Communications of the Association for Information Systems, 26, 359-428.

30. Valacich, J., Schneider, C. (2012). Information Systems Today: Managing in the Digital World $5^{\text {th }}$ ed. New Jersey: Prentice Hall. 